\title{
MENINGKATKAN KETERAMPILAN BERBICARA SISWA DENGAN MENGGUNAKAN MODEL PEMBELAJARAN TIME TOKEN PADA PELAJARAN BAHASA INDONESIA KELAS V SD NEGERI 106226 PADANG BARU
}

\author{
Robenhart Tamba \\ Surel: robenhart@gmail.com
}

\begin{abstract}
ABSTRAK
Tujuan penelitian ini adalah untuk meningkatkan keterampilan berbicara siswa melalui model pembelajaran Time Token di SD Negeri 106226 Padang Baru Kecamatan Dolok Masihol Kabupaten Deliserdang. Subjek penelitian terdiri atas 22 orang siswa. Alat pengumpulan data yang digunakan adalah observasi. Hasil penelitian pada siklus I pertemuan I terdapat 6 orang siswa yang terampil berbicara $(27,27 \%)$ dan 16 siswa yang tidak terampil $(72,72 \%)$, nilai rata-rata kelas 58,95. Pada siklus I pertemuan II, terdapat 13 orang siswa terampil berbicara $(59,09 \%)$, dan 9 orang siswa tidak $(40,90 \%)$, nilai rata-rata 69,40. Siklus II pertemuan I terdapat 15 orang siswa terampil berbicara $(68,18 \%)$ dan 7 orang siswa tidak terampil berbicara $(31,81 \%)$, nilai rata-rata 79,18 . Siklus II pertemuan II, terdapat 20 orang siswa terampil berbicara $(90,09 \%)$ dan 2 orang siswa tidak terampil $(9,09 \%)$, nilai rata-rata kelas 88 .
\end{abstract}

Kata kunci : Model Pembelajaran, Keterampilan Berbicara, Time Token

\section{PENDAHULUAN}

Di sekolah dasar pembelajaran berbicara telah diberikan pada pelajaran Bahasa Indonesia di setiap tingkatan kelas, namun pada kenyataan di lapangan pembelajaran berbicara masih kurang mendapat perhatian dari siswa, jika demikian merupakan hal yang wajar jikalau siswa Sekolah Dasar belum memiliki bekal yang memadai untuk dapat dan terampil dalam berbicara. Situasi seperti ini bukan sepenuhnya terjadi karena kesalahan siswa, namun bisa juga terjadi karena kurangnya model pembelajaran yang dikuasai guru dalam menerapkan materi pembelajaran.

Oleh karena itu, sudah selayaknya dalam kegiatan belajar mengajar guru harus menanamkan konsep keterampilan berbicara

Bahasa Indonesia dalam suasana yang aktif dan menyenangkan, sehingga siswa merasa bahwa belajar Bahasa Indonesia itu tidak sulit dan tidak membosankan. Selain itu, guru dapat memvariasikan cara mengajarnya dengan menggunakan model pembelajaran kooperatif. Model pembelajaran kooperatif digunakan untuk mempengaruhi perhatian siswa agar sepenuhnya tertuju pada kegiatan belajar mengajar sehingga dapat meningkatkan hasil belajar siswa.

Salah satu alternatif yang dapat digunakan untuk meningkatkan keterampilan berbicara siswa kelas V Sekolah Dasar 106226 Padang Baru pada pelajaran Bahasa Indonesia 
yaitu dengan menggunakan model pembelajaran Time Token.

Peneliti sangat tertarik untuk memperbaiki suasana kelas agar lebih aktif dan bersemangat. Maka atas dasar latar belakang tersebut peneliti merasa tertarik untuk melakukan penelitian dengan judul yang diharapkan dapat "Meningkatkan Keterampilan Berbicara Siswa Dengan Menggunakan Model Pembelajaran Time Token pada Pelajaran Bahasa Indonesia di kelas V SD Negeri 106226 Padang Baru Tahun Ajaran 2015-2016".

Dalam menyampaikan suatu pendapat, gagasan, ide atau perasaaan, siswa tidak hanya dituntut untuk mampu "berbicara", namun lebih dari pada itu. Siswa dituntut untuk "terampil" dalam mengeluarkan setiap kata-katanya pada saat berbicara. Hal ini bertujuan untuk meningkatkan keterampilannya dalam menggunakan kosa kata yang dimilikinya dalam menyampaikan sesuatu.

Menurut Arsjad dan Mukti U.S, "keterampilan berbicara adalah kemampuan mengucapkan kalimatkalimat untuk mengekspresikan, menyatakan, menyampaikan pikiran, gagasan dan perasaan.Sedangkan menurut Pangeyasa (2004:43) "keterampilan berbicara adalah kemampuan mengungkapkan pendapat atau pikiran dan perasaan kepada sesorang atau sekelompok orang secara lisan baik berhadapan ataupun jarak jauh”. Tarigan (2007:3) mengatakan bahwa "keterampilan berbicara merupakan suatu keterampilan berbahasa yang berkembang pada kehidupan anak, yang hanya didahului oleh keterampilan menyimak, dan pada masa tersebutlah kemampuan berbicara atau berujar dipelajari”.

Jadi dapat disimpulkan bahwa, keterampilan berbicara merupakan kemampuan mengungkapkan pendapat, gagasan dan perasaan dalam betuk pengucapan kalimat-kalimat kepada seseorang atau sekelompok orang, dan keterampilan berbicara merupakan keterampilan yang di dahului oleh keterampilan menyimak. Istarani (2012:194) menyatakan bahwa, "Model pembelajaran Time Token merupakan model pembelajaran yang digunakan dalam rangka meningkatkan kemampuan siswa untuk berbicara di depan orang lain atau di depan umum, sehingga ia memiliki skill atau kemampuan untuk mengemukakan pendapatnya di depan orang banyak". Aris Shoimin (2014:16) mengatakan bahwa, "model pembelajaran ini (Time Token) mengajak siswa aktif sehingga tepat digunakan dalam pembelajaran berbicara dimana pembelajaran ini benar-benar mengajak siswa untuk aktif dan belajar berbicara di depan umum, mengungkapkan pendapatnya tanpa harus merasa takut dan malu." Dengan demikian dapat disimpulkan bahwa model pembelajaran time token merupakan salah satu model pembelajaran kooperatif yang 
digunakan untuk melatih kemampuan berbicara siswa dengan menggunakan kupon waktu agar siswa tidak mendominasi pembicaraan atau diam sama sekali.

Time token pada dasarnya merupakan sebuah varian diskusi kelompok dimana ciri khasnya adalah setiap siswa diberi kupon bicara \pm 30 detik waktu berbicara. Apabila siswa telah menghabiskan kuponnya, siswa itu tidak dapat berbica lagi. Sudah tentu ini menghendaki agar siswa yang masih pegang kupon untuk ikut berbicara dalam diskusi itu. Cara ini menjamin keterlibatan semua siswa. Cara ini juga merupakan upaya yang sangat baik untuk meningkatkan tanggung jawab individual dalam diskusi kelompok.

Model pembelajaran kooperatif tipe Time token adalah suatu model pegajaran guru dengan menggunakan pembelajaran kooperatif yang secara tekniknya dapat membantu siswa belajar di setiap mata pelajaran dimana siswa bekerja dalam kelompok-kelompok kecil, saling membantu belajar satu sama lainya dengan beranggotakan 5-6 siswa atau lebih dengan memberikan kupon bicara pada siswa di masing-masing kelompok, patokan bicara disini adalah bicara sesuai dengan materi yang dibahas atau mempresentasikan materi, bukan bicara yang asal-asalan yang tidak ada hubungannya dengan materi. Kemudian secara acak guru menunjuk salah satu dari kelompok untuk menjawab pertanyaan atau mempresentasikan di depan kelas, dengan menggunakan kupon bicara tersebut.

\section{METODE PENELITIAN}

Penelitian ini merupakan penelitian tindakan kelas dengan dua siklus. Penelitian dilakukan pada siswa kelas V SD Negeri No. 106626 Padang Baru, Kecamatan Dolok Masihul Tahun Ajaran 2015/2016. Penelitian ini dilaksanakan pada semester ke II, mulai dari bulan Januari 2016 (tahap persiapan) sampai dengan bulan Maret 2016.

Subjek dari penelitian ini adalah seluruh siswa kelas V SDN 106626 Tahun Ajaran 2015/2016 yang berjumlah 22 orang. Adapun Objek dari Penelitian ini adalah sebagai upaya meningkatkan keterampilan berbicara siswa dalam pelajaran Bahasa Indonesia melalui model pembelajaran time token.

Tingkat keberhasilan dalam penelitian ini adalah bila hasil keterampilan berbicara siswa dalam pelajaran Bahasa Indonesia khususnya dalam mengomentari permasalahan faktual mengalami peningkatan. Hal ini dapat dilihat dari hasil tes yang diberikan kepada siswa pada setiap siklusnya. Siswa dikatakan tuntas belajar jika memperoleh nilai 70 , pembelajaran secara klasikal terpenuhi jika persentase ketuntasan mencapai minimal $80 \%$ dari jumlah seluruh siswa Zainal Aqib (2009). 
HASIL DAN PEMBAHASAN

\section{Hasil Penelitian Siklus 1}

Berdasarkan observasi awal yang dilakukan peneliti, dapat diketahui bahwa keterampilan berbicara siswa pada mata pelajaran bahasa Indonesia masih rendah. Hal ini disebabkan karena guru kurang memberdayakan model pembelajaran yang tepat dalam proses pembelajaran. Oleh karena itu, untuk mengatasi masalah tersebut peneliti menggunakan model pembelajaran time token untuk meningkatkan keterampilan berbicara siswa pada mata pelajaran bahasa Indonesia pada pokok bahasan mengomentari persoalan faktual. Dari hasil pelaksanaan siklus 1 pertemuan 1 didapat skor persentase observasi keterampilan berbicara siswa masih tergolong rendah dengan nilai ratarata 58,95. Dari 22 orang siswa terdapat 11 orang siswa yang mendapat kategori sangat kurang terampil $(50 \%), 5$ orang siswa yang mendapat kategori kurang terampil $(22,72 \%)$, dan 3 orang siswa yang mendapat kategori cukup terampil $(13,63 \%), 2$ orang siswa yang mendapat kategori terampil $(9.09 \%)$ dan 1 orang siswa sangat terampil $(4,54 \%)$.

Hasil yang diperoleh siswa pada siklus 1 pertemuan 1 belum sesuai dengan yang diharapkan, persentase keterampilan berbicara siswa baik secara individu maupun klasikal masih rendah. Dengan kata lain, penelitian dikatakan belum berhasil atau tuntas karena belum mencapai $75 \%$ tingkat ketuntasan yang ingin dicapai. Pelaksanaan Siklus 1 Pertemuan II memberikan hasil keterampilan berbicara siswa masih tergolong rendah dengan nilai rata-rata 69,40. Dari 22 orang siswa terdapat 4 orang siswa yang mendapat kategori sangat kurang terampil $(18,8 \%), 5$ orang siswa yang mendapat kategori kurang terampil $(22,72 \%), 7$ orang siswa yang mendapat kategori cukup terampil $(31,81 \%), 4$ orang siswa yang mendapat kategori terampil $(14,8 \%)$ dan 2 orang siswa yang mendapat kategori sangat terampil (9,09\%). Hasil yang diperoleh siswa pada siklus I pertemuan II ini belum sesuai dengan yang diharapkan, persentase keterampilan berbicara siswa baik secara individu maupun klasikal masih rendah.

\section{Refleksi Siklus I}

Berdasarkan hasil perolehan data keterampilan berbicara siklus 1 , dapat dikatakan bahwa hasil yang diperoleh masih belum memenuhi target yang ingin dicapai. Masih banyak siswa yang belum mampu mengemukakan pendapat mereka dengan baik dan benar, penguasaan kosa kata yang minim, intonasi yang kurang tepat, ketidakberanian siswa dalam melakukan kontak mata terhadap lawan bicara mereka pada saat mengemukakan pendapatnya serta suasana kelas yang ribut pada saat kelompok lain sedang tampil membacakan hasil diskusi di depan kelas. Keterampilan berbicara siswa 
yang masih rendah ini terlihat dari hasil persentase keterampilan berbicara yang hendak dicapai belum tercapai. Ketuntasan keterampilan berbicara siswa pada siklus I secara klasikal diperoleh 13 orang siswa $(59,09 \%)$. Berdasarkan hal tersebut, peneliti mencari faktor penghambat dan pendukung dari pelaksanaan yang telah dilaksanakan.

a. Faktor Penghambat

1. Siswa masih belum siap menghadapi situasi pembelajaran yang baru diterapkan peneliti yaitu dalam hal menggunakan model pembelajaran time token yang dibantu dengan menggunakan kartu kupon berbicara

2. Sifat kurang percaya diri dan tidak peduli siswa membuat waktu terbuang percuma.

3. Masih adanya siswa yang suka curi perhatian, ribut di kelas dan tidak mau berbicara.

4. Kurangnya kosa kata yang dimiliki siswa dalam mengemukakan pendapatnya mengenai suatu persoalan, yang mengakibatkan pengggunaan kalimat masih rendah.

b. Faktor Pendukung

1. Siswa merasa senang karena ada guru baru yang mengajar mereka.

2. Siswa cukup antusias mengikuti pelajaran karena melakukan diskusi dengan cara baru yaitu mengunakan kartu kupon.

\section{Hasil Penelitian Siklus II}

Dari hasil refleksi siklus I dapat disimpulkan bahwa pelaksanaan kegiatan belajar mengajar belum begitu baik sehingga keterampilan berbicara siswa belum meningkat. Perencanaan tindakan yang dilakukan pada siklus II adalah dengan memperbaiki kekurangan yang terjadi bersikap tegas terhadap siswa yang malas dan siswa yang suka ribut di kelas, guru diharapkan selalu mengawasi tingkah laku siswa tanpa mengabaikan siswa yang lain.

Pada tahap ini siklus II tidak berbeda jauh dengan yang dilakukan pada siklus I. Perencanaan tindakan pada siklus II ini dilakukan berdasarkan hasil refleksi dan analisis data yang dilakukan pada siklus I. Adapun kegiatan yang dilakukan pada tahap ini adalah peneliti yang berperan sebagai guru mengembangkan indikator pencapaian keterampilan berbicara siswa, mengembangkan materi pelajaran, meningkatkan motivasi siswa dalam mengikuti proses pembelajaran, memperbaiki pelaksanaan pembelajaran melalui model pembelajaran time token, menyiapkan silabus, RPP, kartu kupon berbicara, sumber belajar dan media pembelajaran yang digunakan untuk mendukung efektivitas pelaksanaan tindakan.

Setelah dilaksanakan siklus II pertemuan I, maka didapat hasil observasi keterampilan berbicara siswa masih tergolong rendah dengan nilai rata-rata 79,18\%. Dari 22 orang 
siswa, terdapat 7 orang siswa yang mendapat kategori kurang terampil $(31,81 \%), \quad 4$ orang siswa yang mendapat kategori cukup terampil $(18,18 \%), 5$ orang siswa yang mendapat kategori terampil $(22,72 \%)$ dan 6 orang siswa yang mendapat kategori sangat terampil $(27,27 \%)$. Meskipun terjadi peningkatan keterampilan berbicara pada sebagian siswa, namun hasil yang dicapai pada siklus II pertemuan I ini masih belum memenuhi target yang ingin dicapai peneliti, yaitu ketuntasan $75 \%$. Hasil ini masih tergolong rendah, baik secara klasikal maupun individu. Dengan kata lain, peneliti masih belum mencapai hasil yang telah ditentukan sebelumnya. Oleh karena itu, peneliti akan melanjutkannya ke siklus II pertemuan ke II.

Setelah dilaksanakan siklus II pertemuan II, maka didapat hasil observasi keterampilan berbicara siswa kelas V SDN 106226 Padang Baru telah meningkat dengan nilai rata-rata kelas 88. Dari 22 orang siswa, teradapat 2 orang siswa yang mendapat kategori kurang terampil (9,09\%), 1 orang siswa mendapat kategori cukup terampil (4,54\%), 7 orang siswa mendapat kategori terampil $(31,81 \%)$ dan 12 orang siswa mendapat kategori sangat terampil (54,54\%). Hal ini menunjukkan bahwa terjadi peningkatan keterampilan berbicara pada siswa kelas V SDN 106226 Padang Baru setelah menggunakan model pembelajaran time token. Peningkatan keterampilan berbicara dapat terlihat baik dari penilaian secara individu maupun penilaian secara klasikal. Dengan demikian, penelitian ini dikatakan berhasil atau tuntas karena telah mencapai ketuntasan keterampilan klasikal sebesar 90\%, dari ketuntasan keterampilan yang telah ditetapkan yaitu $75 \%$.

Berikut merupakan rekapitulasi peningkatan keterampilan berbicara dari mulai siklus I sampai II seperti pada diagram di bawah ini:

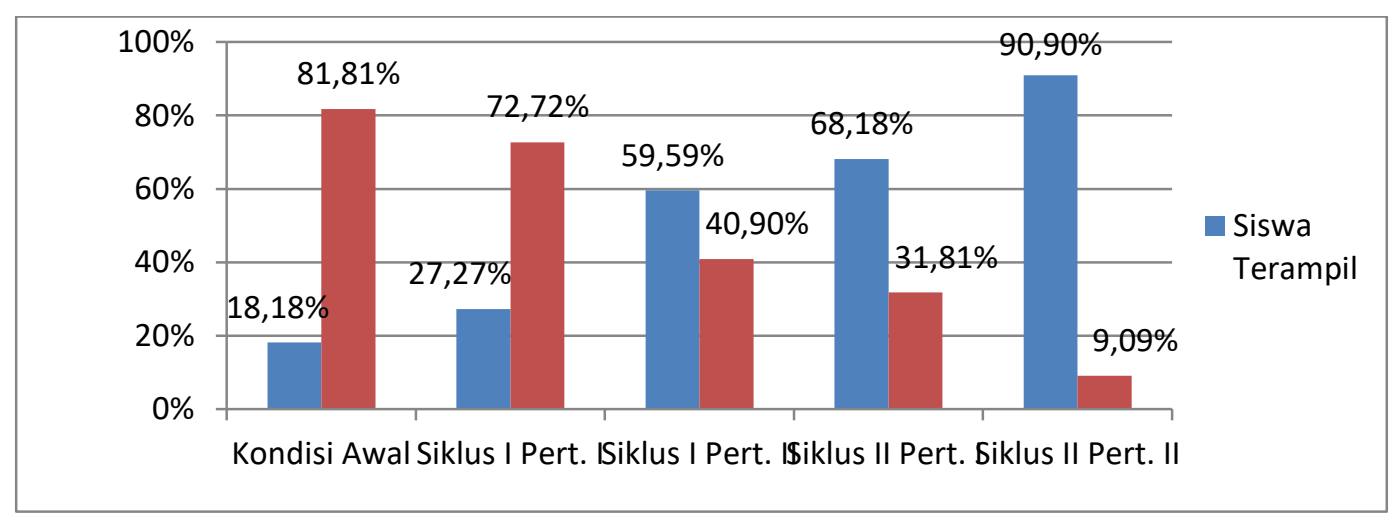

\section{Diagram Grafik Rekapitulasi Persentase Peningkatan Keterampilan Berbicara Siswa}


Pembahasan Hasil Penelitian

Secara umum, keterlibatan siswa dalam proses pembelajaran bahasa Indonesia pada pokok bahasan persoalan faktual pada kelas V SDN 106226 Padang Baru dengan menggunakan model pembelajaran time token dapat terlihat perubahan dengan meningkatnya persentase berbicara siswa yang terlihat pada tabel di bawah ini:

Tabel Hasil Keterampilan Berbicara Siswa Sebelum dan Sesudah Siklus

\begin{tabular}{|c|c|c|c|c|c|c|}
\hline \multirow[b]{2}{*}{ No } & \multirow{2}{*}{$\begin{array}{c}\text { Pencapaian } \\
\text { Keterampilan } \\
\text { Berbicara }\end{array}$} & \multirow{2}{*}{$\begin{array}{l}\text { Kondisi } \\
\text { Awal }\end{array}$} & \multicolumn{2}{|c|}{ Siklus I } & \multicolumn{2}{|c|}{ Siklus II } \\
\hline & & & Pert I & Pert II & Pert I & Pert II \\
\hline 1 & $\begin{array}{l}\text { Jumlah siswa yang } \\
\text { terampil }\end{array}$ & $\begin{array}{l}4 \text { orang } \\
\text { siswa } \\
(18,18 \%)\end{array}$ & $\begin{array}{l}6 \quad \text { orang } \\
\text { siswa } \\
(27,27 \%)\end{array}$ & $\begin{array}{l}13 \text { orang } \\
\text { siswa } \\
(59,09 \%)\end{array}$ & $\begin{array}{l}15 \text { orang } \\
\text { siswa } \\
(68,18 \%)\end{array}$ & $\begin{array}{l}20 \text { orang } \\
\text { siswa } \\
(90,90 \%)\end{array}$ \\
\hline 2 & $\begin{array}{l}\text { Jumlah siswa yang } \\
\text { tidak terampil }\end{array}$ & $\begin{array}{l}18 \text { orang } \\
\text { siswa } \\
(81,81 \%)\end{array}$ & $\begin{array}{l}16 \text { orang } \\
\text { siswa } \\
(72,72 \%)\end{array}$ & $\begin{array}{l}9 \text { orang } \\
\text { siswa } \\
(40,90 \%)\end{array}$ & $\begin{array}{l}7 \text { orang } \\
\text { siswa } \\
(31,81 \%)\end{array}$ & $\begin{array}{l}2 \text { orang } \\
\text { siswa } \\
(9,09 \%)\end{array}$ \\
\hline
\end{tabular}

Dari tabel tersebut dapat diketahui bahwa siswa yang terampil dalam berbicara pada siklus I pertemuan I sebanyak 6 orang siswa $(27,27 \%)$ dan yang belum terampil sebanyak 16 orang siswa $(72,72 \%)$, pada siklus I pertemuan II sebanyak 13 orang siswa $(59,09 \%)$ yang terampil berbicara dan yang belum terampil sebanyak 9 orang siswa (40,90\%). Pada siklus II diperoleh hasil keterampilan berbicara siswa, dimana pada siklus II pertemuan I sebanyak 15 orang siswa $(68,18 \%)$ yang dinyatakan terampil dan sebanyak 7 orang siswa $(31,81 \%)$ yang dinyatakan tidak terampil berbicara. Pada siklus II pertemuan II sebanyak 20 orang siswa $(90,09 \%)$ yang dinyatakan terampil dan sebanyak 2 orang siswa $(9,09 \%)$ yang dinyatakan tidak terampil berbicara.
Dengan demikian, dapat disimpulkan bahwa terjadi peningkatan keterampi-lan berbicara dengan menggunakan model pembelajaran time token pada siswa kelas V SDN 106226 Padang Baru.

Hasil observasi awal yang dilakukan peneliti sebelum melakukan tindakan ialah masih banyak ditemui siswa yang tidak terampil dalam berbicara. Hanya 3 orang siswa saja yang mampu terampil dalam berbicara, sementara 19 orang siswa lainnya masih raguragu, malu-malu dan bahkan beberapa siswa tidak berani berbicara. Oleh karena itu, peneliti melakukan suatu model pembelajaran, yaitu model pembelajaran time token yang diharapkan penggunanya dapat meningkatkan keterampilan berbicara 
siswa. Setelah pemberian pelajaran dengan menggunakan model pembelajaran time token yaitu dengan cara memberikan kartu kupon berbicara yang berjumlah 2 buah kepada setiap siswa dalam mengikuti pelajaran bahasa Indonesia pada materi pokok persoalan faktual di SDN 106226 Padang Baru. Pada siklus I pertemuan I keterampilan berbicara siswa secara klasikal yaitu $(27,27 \%)$. Pada siklus I pertemuan II keterampilan berbicara siswa meningkat menjadi $(59,09 \%)$.

Berdasarkan hasil pada siklus I dalam 2 kali pertemuan, maka diperoleh kesimpulan bahwa penggunaan model pembelajaran time token dalam meningkatkan keterampilan berbicara siswa yang dilakukan peneliti masih belum optimal dalam penggunaanya, maka peneliti perlu melanjutkan ke siklus II

Siklus II yang merupakan perbaikan dari siklus I melalui penggunaan model pembelajaran time token menunjukkan perubahan hasil yang meningkat. Pada siklus II pertemuan I, diperoleh tingkat ketuntasan keterampilan berbicara siswa secara klasikal sebesar $(68,18 \%)$. Kemudaian dilanjutkan pada siklus II pertemuaan II yang memperoleh hasil ketuntasan keterampilan berbicara siswa secara klasikal yaitu sebanyak (90,09\%).

Dengan

demikian, berdasarkan hasil penelitian yang telah dilakukan oleh peneliti serta observasi yang dilakukan dari siklus I hingga siklus II, penggunaan model pembelajaran time token yang diterapkan oleh peneliti secara klasikal dipandang baik dan dapat meningkatkan keterampilan berbicara siswa pada mata pelajaran bahasa Indonesia pada materi pokok persoalan faktual siswa kelas V SDN 106226 Padang Baru.

\section{KESIMPULAN}

Berdasarkan hasil dan pembahasan penelitian tindakan kelas ini, maka dapat diambil kesimpulan bahwa model pembelajaran time token dapat meningkatkan keterampilan berbicara siswa. Keberhasilan yang dilakukan oleh peneliti dengan model pembelajaran time token dapat dilihat dari hasil penelitian yang didapat oleh peneliti selama di lapangan:

1. Pada kondisi awal jumlah siswa yang terampil berbicara 4 orang dengan persentase (18\%) dan yang tidak terampil 18 orang dengan persentase $82 \%$.

2. Pada siklus I hasil yang dicapai tidak sesuai dengan target ketercapaian nilai, karena hanya $(59,09 \%)$ siswa yang terolong pada kategori tuntas.

3. Pada siklus II hasil yang diperoleh sudah sangat cukup dan layak, yakni sudah mencapai ketuntasan (90,09\%). Dan setelah dilakukan tindakan siklus II ini maka peneliti tidak perlu melakukan penelitian pada siklus selanjutnya. 
Berdasarkan hasil penelitian yang dilakukan maka peneliti memberi saran sebagai berikut:

1. Agar guru menerapkan model pembelajaran time token di dalam pembelajaran karena terbukti dapat meningkatkan keterampilan berbicara siswa.

2. Agar kepala sekolah membuat program pembelajaran dengan menggunakan model pembelajaran time token di sekolah dasar karena hal ini dapat meningkatkan hasil prestasi belajar.

3. Pihak sekolah kiranya, perlu untuk melengkapi sarana dan prasarana pembelajaran. Serta mengadakan pelatihan kepada guru tentang penggunaan model pembelajaran, sehingga dapat meningkatkan keterampilan berbicara siswa.

\section{DAFTAR RUJUKAN}

Aqib, Zainal. 2008. Penelitian Tindakan Kelas. Bandung: Yrama Widya.

Arends, Richard. 2008. Learning to Teach. Yogyakarta: Pustaka Belajar.

Arikunto. 2008. Penelitian Tidakan Kelas. Jakarta: Bumi Aksara.

Dewi, Rosmala. 2010. Professional Guru Melalui Penelitian Tindakan Kelas. Medan: Pasca Sarjana Unimed.
Dwijastuti, MG. 2015. Peningkatan Keterampilan Berbicara Menggunakan Model Pembelajaran Time Token Arends di SD Negeri 02 Klodran. Solo: Jurnal Didaktika 3:5.

Istarani. 2012. 58 Model Pembelajaran Inovatif. Medan: Media Persada.

Muhibbinsyah. 2010. Psikologi Pendidikan. Bandung: Remaja Rosdakarya.

Oktavirani, Dewi. 2015. Keefektifan Model Time Token pada Pembelajaran Keterampilan Berbicara. Jurnal Pendidikan Bahasa dan Sastra Indonesia.4:8

Pangeyasa, W. 2004. Peningkatan Kemampuan Berbicara Siswa Kelas 1 MTs Sunan Kalijogo Malang Melalui Strategi Pemetaan Pikiran. Tesis. Malang: Pascasarjana Universitas Negeri Malang.

Shoimin, Aris. 2014. 68 Model Pembelajaran Inovatif dalam Kurikulum 2013. Yogyakarta: Ar- Ruzz Media.

Slameto. 2010. Belajar dan Faktorfaktor yang Mempengaruhinya. Jakarta: Rineka Cipta. 
Robenhart Tamba: Meningkatkan Keterampilan ...

Suprijono, Agus. 2010. Cooperative Learning. Yogyakarta: Pustaka Belajar.

Tarigan, Guntur. 2008. Berbicara Sebagai Suatu Keterampilan Berbahasa. Bandung: Angkasa Bandung.

Trianto. 2009. Mendesain Pembelajaran Inovatif Progresif. Jakarta: Kencana Prenada Media Group.

Umi, Rafika. 2015. Peningkatan Keterampilan Berbicara Siswa Menggunakan Model Pembelajaran Time Token SMA Kemala Bhayankari 1 Pontianak. Jurnal Pendidikan dan Pembelajaran. 4:8. 